\title{
Pemberdayaan Masyarakat Melalui Pembuatan Laporan Keuangan Sederhana Keluarga Pada Ibu-ibu PKK Citra Villa
}

\author{
Putri Nurmala1, Wahyu Nurul Hidayati², Akhmad Sigit Adiwibowo ${ }^{3}$, \\ Shinta Ningtiyas Nazar ${ }^{4}$, Listiya Ike Purnomo ${ }^{5}$, Anis Syamsu Rizal ${ }^{6}$ \\ Program Studi S1 Akuntansi Universitas Pamulang Tangerang Selatan \\ Email: 1pnurmala@gmail.com, ${ }^{2}$ wahyu.nuhi@gmail.com, \\ 3akhmad.s.adiwibowo@gmail.com, ${ }^{4}$ dosen00801@unpam.ac.id, \\ 5dosen00799@unpam.ac.id, ${ }^{6}$ anissyamsurizal@gmail.com
}

\begin{abstract}
It's expected that the PKK Citra Villa Women's Organization will empower womento participate in the development of Bambu Apus Village, Pamulang, South Tangerang. In its implementation, PKK Citra Villa Women's Organization often faces obstacles when it comes to making an accountability report in the form of monthly and annual financial reports. Therefore, the community service activities aim to transfer knowledge and techniques for making simple financial statements for PKK Citra Villa, so PKK Citra Villa Women's Organization can be independent in making her financial statements. As for the method carried out in the form of material delivery and practice / application of financial reporting. Results The activity showed that before the PKM implementation the PKK Citra Villa Women's Organization were lacking master about simple financial reports, but after the implementation of the activity known to the PKK Citra Villa Women's Organization is quite expert and can make simple financial reports. Activities PKM indirectly plays a positive role in increasing the knowledge of participants and the skills of participants in making simple financial reports.
\end{abstract}

Key Words: Family Welfare Development (PKK), Reports, Finance

\section{Pendahuluan}

Pengabdian kepada masyarakat (PKM) dapat diartikan sebagai respon akademik masyarakat kampus atas kebutuhan, tantangan, atau persoalan yang dihadapi oleh masyarakat, baik secara langsung maupun tidak langsung. Berbekal kompetensi keilmuan yang dimiliki, kegiatan ini merupakan 
aktualisasi dari tanggungjawab dan kepedulian sosial warga kampus kepada masyarakat luas, yang meliputi usaha-usaha nyata untuk meningkatkan kualitas sumber daya manusia melalui perluasan wawasan dan pengetahuan, serta peningkatan keterampilan hidup.Terkandung di dalamnya partisipasi aktif, kreatif, dan inovatif warga kampus dalam berbagai bentuk community development yang bersifat transformatif, sehingga masyarakat mampu mencapai kehidupan yang lebih baik (mandiri dan bermartabat).

PKM dapat dilakukan di dunia bisnis ataupun rumah tangga, bahkan dikeduanya. Mengenai bisnis, kita mengetahui bisnis yang baik tentunya harus diiringi dengan pembukuan finansial yang memadai agar pengeluaran dan pemasukan usaha dapat dimonitor secara akurat. Selain itu, pembukuan yang benar juga akan bermanfaat dalam membantu mengambil keputusan dan pertanggungjawaban bisnis. Dengan demikian, pembukuan yang benar juga merupakan hal yang sangat penting dalam memulai bisnis baru agar dapat lebih menjamin keberlangsungan usaha. Pastikan selalu fokus saat sedang melakukan pembukuan untuk meminimalisi kekeliruan yang dapat membawa dampak fatal bagi pertumbuhan usahamu. Perlu diingat juga kalau pembukuan hanyalah langkah awal untuk memproses akuntansi perusahaan. Pada akhirnya, seluruh data yang sudah Anda kumpulkan harus diterjemahkan melalui proses akuntansi agar kondisi finansial perusahaan terlihat dengan jelas. Kombinasi pembukuan yang benar dan proses akuntansi adalah kunci untuk mengambil keputusan-keputusan jitu berbisnis.

Sama halnya dengan di perusahaan, rumah tangga juga memerlukan pembukuan akuntansi dan laporan keuangan sederhana. Namun, kami melihat fenomena gap dimana banyak sekali keluarga yang melakukan 'gali lubang. tutup lubang' dalam keuangan rumah tangganya. Banyaknya rumah tangga yang melakukan hal ini dapat mengindikasikan masyarakat belum 
sejahtera. Salah satu upaya untuk meningkatkan kesejahtaraan masyarakat di Kelurahan Bambu Apus, dibentuklah suatu badan / organisasi untuk melakukan pembinaan dan kesejahteraan keluarga dilingkungan Citra Villa, Bambu Apus. Organisasi tersebut adalah Ibu-ibu Pembinaan Kesejahteraan Keluarga (PKK) Citra Villa.

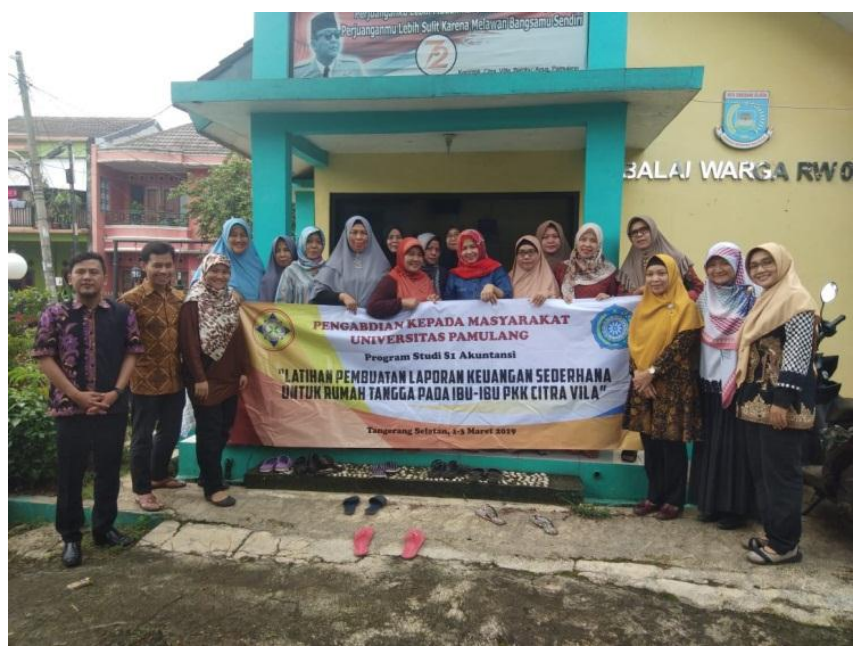

Gambar 1. Tim Dosen PKM Unpam dan Ibu-ibu PKK Citra Villa di depan Balai Warga RW 02 Bambu Apus (Sumber: Dokumentasi, 2019)

Namun, ternyata ibu-ibu anggota PKK Citra Villa pun masih memiliki pemahaman yang kurang terhadap laporan keuangan, serta sebagian besar ibu-ibu yang menjadi anggota PKK tidak memiliki kompetensi dibidang yang bersangkutan. Berdasarkan wawancara terhadap ibu-ibu anggota PKK yang bertugas membuat laporan keuangan ditemukan bahwa salah satu penyebab kesulitan dalam pembuatan laporan keuangan disebabkan basic pendidikan yang tidak memiliki kompetensi di bidang laporan keuangan. Sedangkan, apabila harus menyerahkan pembuatan laporan keuangan kepada pihak luar diperlukan biaya yang tidak sedikit padahal organisasi Ibu-ibu PKK bukan merupakan organisasi yang mencari keuntungan sehingga dirasa sangat menyulitkan. 
Melihat kenyataan perlu dan mendesaknya kebutuhan Ibu-ibu PKK Citra Villa akan keterampilan membuat laporan keuangan, maka dirasa perlu adanya pelatihan pembuatan laporan keuangan sedarhana bagi Ibu-ibu PKK Citra Villa, Kelurahan Bambu Apus, Pamulang, Tangerang Selatan guna meningkatkan kompetensi dan pemahaman mengenai tata cara pembuatan laporan sederhana yang pada akhirnya diharapkan Ibu-ibu PKK Citra Villa nantinya dapat membuat laporan keuangan mandiri.

\section{Metode}

Metode yang dilakukan dalam kegiatan pengabdian kepada masyarakat ini dilakukan dengan melakukan pendekatan meliputi pendekatan dalam proses penyampaian pengetahuan mengenai pembuatan laporan keuangan sederhana kepada ibu-ibu PKK Citra Villa sehingga peserta pengabdian (Ibuibu PKK Citra Villa) dapat mengetahui tata cara pembuatan laporan keuangan sederhana bagi organisasi yang dilanjutkan dengan pelatihan pembuatannya secara langsung, dimana kegiatan tersebut berlangsung sejak tanggal 1-3 Maret 2019.

\section{Penyampaian Pengetahuan Mengenai Pembuatan Laporan} Keuangan Sederhana

Langkah awal metode pelaksanaan kegiatan pengabdian ini yaitu penyampain pengetahuan mengenai pembuatan laporan keuangan sederhana pada Ibu-Ibu PKK Citra Villa. Kegiatan ini dilakukan dengan tatap muka secara langsung yang disertai diskusi dan tanya jawab mengenai materi yang disampaiakan. Adapun materi yang disampaian mengenai pembuatan laporan keuangan sederhana yang meliputi:

a. Analisis Neraca

Analisis neraca keuangan ditujukan untuk mengetahui posisi keuangan dari organisasi dalam hal ini PKK Citra Villa pada suatu 
periode tertentu. Neraca merupakan bagian dari laporan keuangan yang dibuat setahun sekali. Neraca memiliki beberapa unsur yang secara garis besar dapat dibagi menjadi tiga meliputi harta, kewajiban dan modal. Melalui analisis neraca ini juga akan bermanfaat bagi peserta sehingga dapat membedakan antara harta, kewajiban maupun modal ${ }^{1}$.

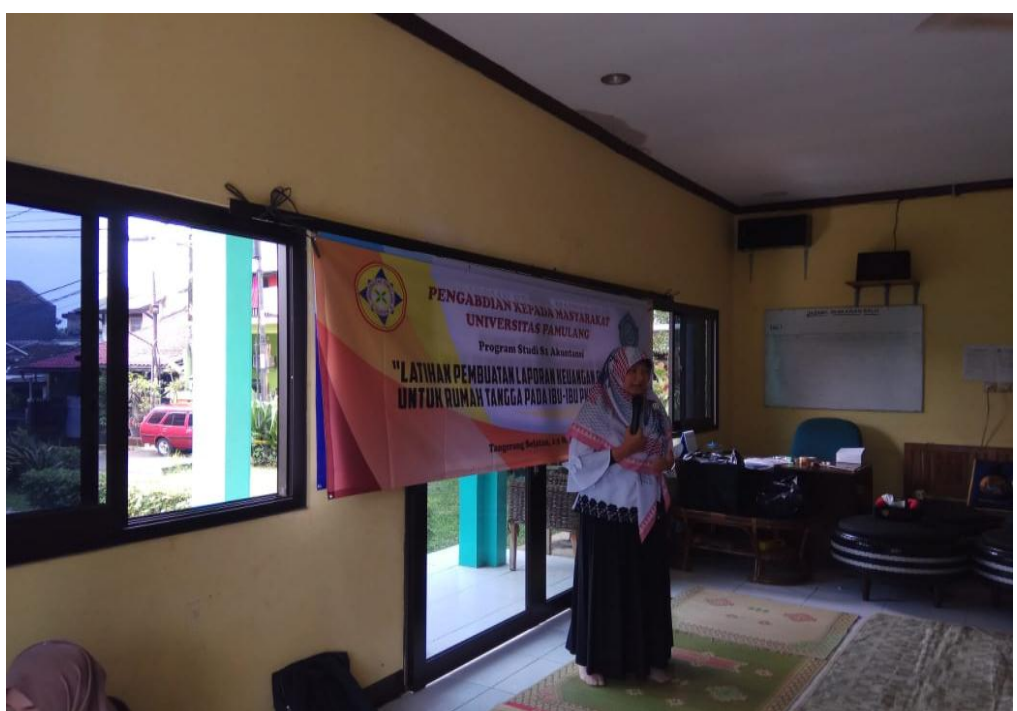

Gambar 2. Proses Penyampaian Materi dari Tim Pemateri PKM (Sumber: Dokumentasi, 2019)

b. Analisis Laporan Laba Rugi

Analisis Laporan laba rugi merupakan analisis yang memuat laporan tentang selisih pendapatan setelah dikurangi dengan biaya-biaya atau beban². Analisis Laporan Laba Rugi dapat bermanfaat bagi peserta untuk mengambil kebijakan atau sebagai dasar ukuran seperti untuk mengukur tingkat pengembalian dari investasi kegiatan.

${ }^{1}$ Hanafi, Mamduh M dan Halim, Abdul. 2007. Analisis Laporan Keuangan Edisi Ketiga. STIE YKPN. Yogyakarta.

${ }^{2}$ Kasmir. 2012. Analisis Laporan Keuangan. PT. Raja Grafindo Persada. Jakarta 
c. Analisis Laporan Perubahan Ekuitas

Laporan perubahan ekuitas adalah laporan yang memuat tentang segala perubahan atau ekuitas untuk suatu periode ${ }^{3}$. Pengetahuan Laporan Perubahan Ekuitas ini sangat bermanfaat bagi peserta sebagai bahan pengetahuan untuk menyusun keuangan keluarga.

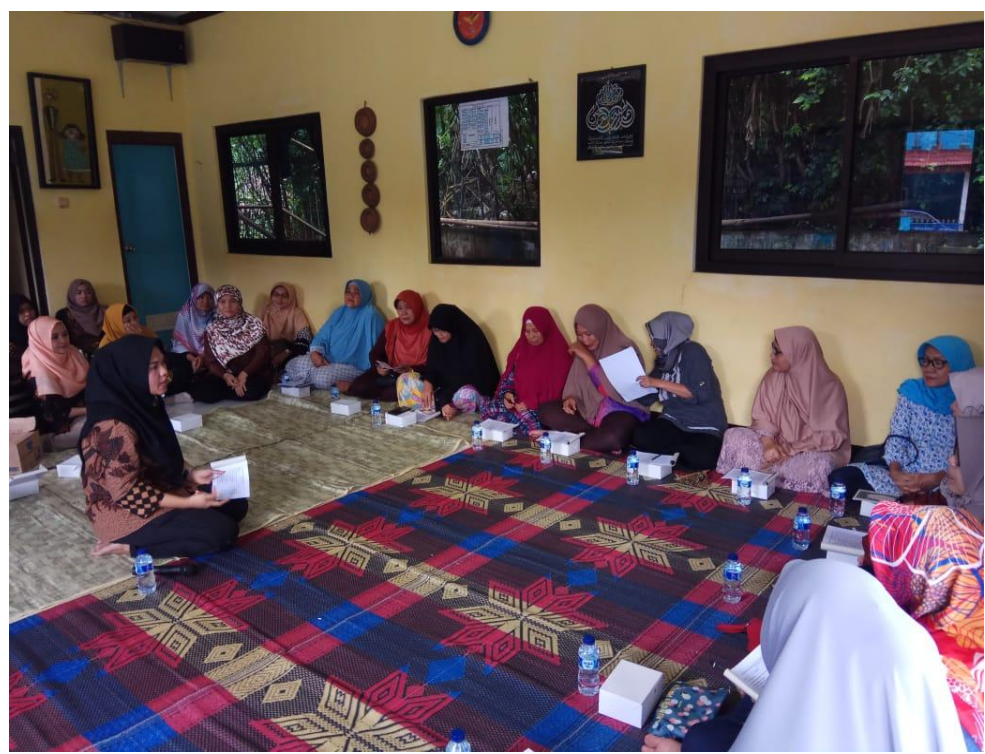

Gambar 3. Peserta Mendengarkan pemaparan materi (Sumber: Dokumentasi, 2019)

\section{d. Analisis Laporan Arus Kas}

Laporan arus kas memuat segala informasi yang berhubungan dengan kas masuk dan kas keluar dalam periode yang telah ditetapkan. Analisis ini sangat bermanfaat bagi peserta terutama sebagai catatan historis atas pengeluaran atau pemasukan yang berhubungan dengan kas 4 . Jakarta.

${ }^{3}$ Jumingan. 2006. Analisis Laporan Keuangan. Cetakan Pertama. PT Bumi Aksara.

4 Sucipto. 2003. Penilaian Kinerja Keuangan. Jurnal Akuntansi. Program Sarjana Universitas Sumatera Utara. Medan. 


\section{Penerapan Pembuatan Laporan Keuangan Sederhana}

Penerapan pembuatan laporan keuangan sederhana dilakukan dengan metode aplikatif yaitu seluruh peserta diberikan data yang berisi histori pengeluaran, pemasukan, harta dan kewajiban dari laporan keuangan yang belum tersusun secara baik (masih berbentuk data mentah) yang selanjutnya setiap peserta diwajibkan untuk mengelompokkan data tersebut pada 7 buku yang telah disediakan yaitu meliputi: Buku kas, persediaan barang, pembelian barang, penjualan, biaya, piutang maupun buku hutang. Setelah dikelompokkan secara benar, masing-masing peserta diminta untuk menyusunnya kedalam laporan keuangan (laporan laba rugi dan neraca).

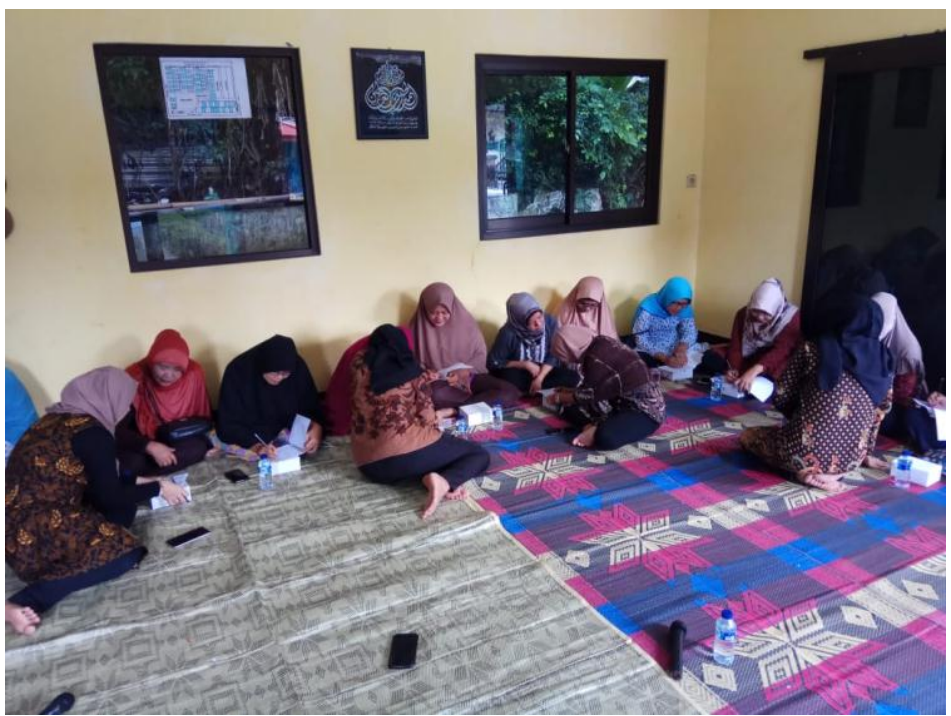

\section{Gambar 4. Pelaksanaan Tes Pembuatan Laporan Keuangan didampingi Tim PKM (Sumber: Dokumentasi, 2019)}

Kegiatan ini bermanfaat sebagai sarana aplikasi atas pengetahuan yang didapat peserta sehingga peserta diharapkan mampu membuat laporan keuanagan sederhana untuk organisasinya dalam hal ini PKK Citra Villa. 


\section{Tahapan Kegiatan Pengabdian}

Kegiatan pengabdian kepada masyarakat ini dimulai dengan melakukan analisis situasi dan koordinasi dengan objek pengbdian kepada masyarakat (PKK Citra Villa), yang dilanjutkan dengan kegiatan inti yang meliputi penyampaian materi mengenai Pengetahuan Pembuan Sederhana dan Penerapan Pembuatan Laporan Keuangan Sederhana yang kemudian diakhiri dengan kegiatan akhir yaitu evaluasi program. Untuk lebih jelasnya, Tahapan kegiatan PKM ini dapat dijelaskan melalui Gambar 5 berikut ini:

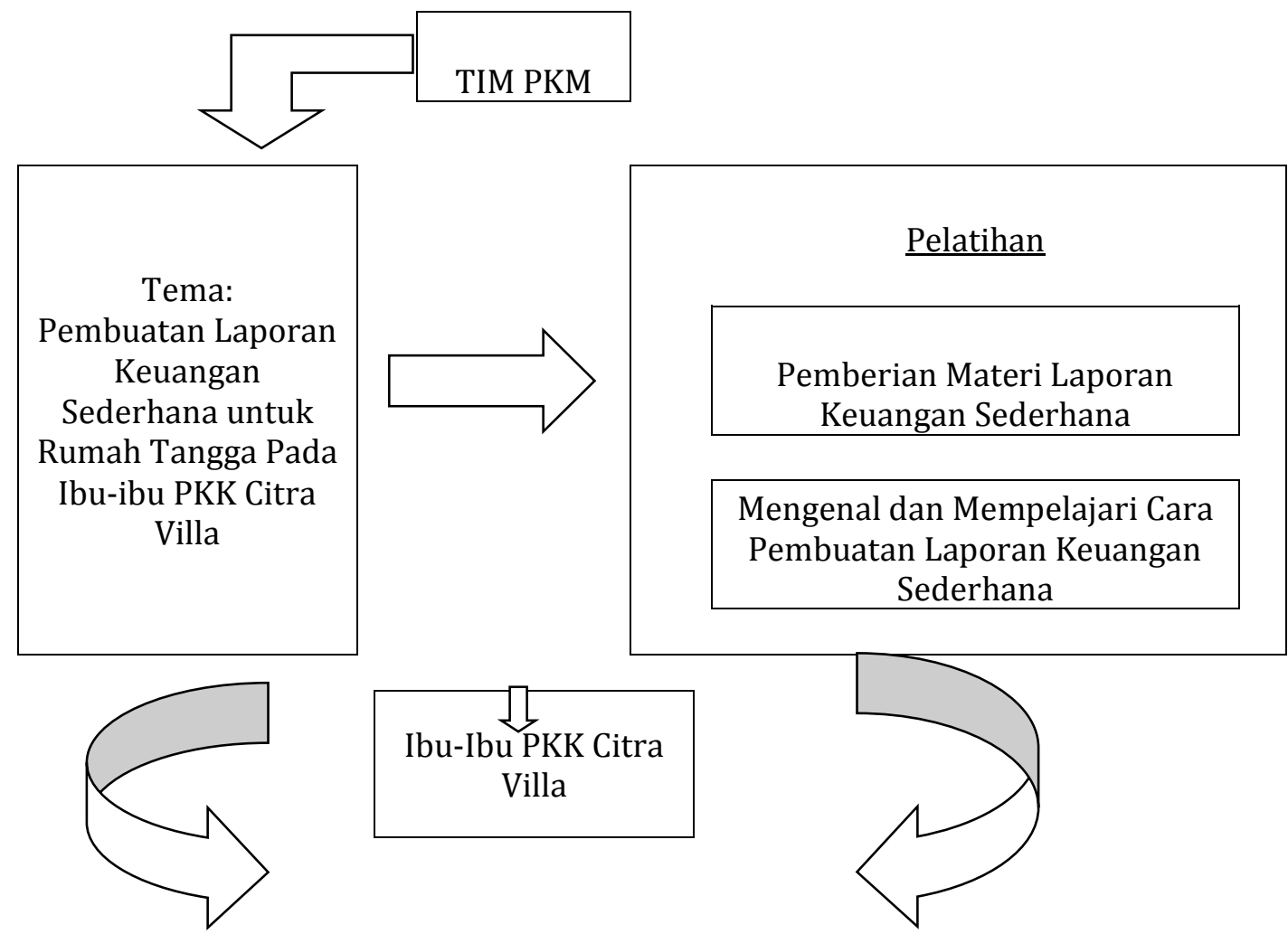

Ibu-Ibu PKK Citra Villa Mampu Membuat Laporan Keuangan Sederhana untuk Rumah Tangga

Gambar 5. Tahapan Kegiatan Pengabdian (Sumber: Dokumentasi, 2019) 


\section{Hasil dan Diskusi}

Keberhasilan kegiatan pengabdian kepada masyarakat salah satunya dapat dilihat dari hasil evaluasi apakah terjadi perbaikan dari peserta pengabdian setelah dilakukan kegiatan. Hasil kegiatan PKM ini dapat dijelaskan sebagai berikut:

\section{Pengetahuan Peserta (Ibu-Ibu PKK Citra Villa) Mengenai} Pembuatan Laporan Keuangan Sederhana Sebelum disampaikan Materi

Berdasarkan hasil pre-test (tes pendahuluan) sebelum dilakukan penyampaian materi mengenai pembuatan laporan keuangan sederhana diketahui bahwa pengetahuan peserta dalam hal ini Ibu-Ibu PKK Citra Villa mayoritas berada di kategori cukup menguasai materi dasar laporan keuangan. Hasil pre-test juga menunjukkan bahwa materi mengenai neraca yang sebenarnya merupakan dasar dari pembuatan laporan keuangan sederhana kurang dikuasai oleh peserta.

Hasil ini menunjukkan bahwa pengetahuan Ibu-Ibu PKK Citra Villa cukup baik terkait dasar-dasar laporan keuangan, namun tetap perlu dilakukan suatu kegiatan yang dapat meningkatkan pemahaman ibuibu PKK mengenai pembuatan laporan keuangan sederhana.

\section{Pengetahuan Peserta (Ibu-Ibu PKK Citra Villa) Mengenai} Pembuatan Laporan Keuangan Sederhana Setelah disampaikan Materi

Tes mengenai pengetahuan peserta dalam hal ini Ibu-ibu PKK Kecamatan Sako mengenai laporan keuangan sederhana setelah disampaikan materi sangat diperlukan untuk mengukur keberhasilan kegiatan penyampaian materi mengenai laporan keuangan sederhana oleh tim pengabdian. Berdasarkan hasil tes setelah penyampaian materi diketahui bahwa pengetahuan peserta mengenai laporan keuangan 
sederhana setelah disampaikan materi mayoritas berada pada kategori menguasai.

Hasil ini juga menunjukkan bahwa terdapat perbedaan yang cukup signifikan antara hasil sebelum dan sesudah kegiatan penyampaian materi. Hal mengindikasikan kegiatan PKM dalam hal ini penyampian materi mengenai laporan keuangan sederhana dapat dikatakan berhasil meningkatkan pengetahuan peserta.

\section{Penerapan Pembuatan Laporan Keuangan Sederhana}

Setelah dilakukan penyampaian materi dan tes setelah penyampaian materi, peserta diarahkan untuk membuat laporan keuangan sederhana, hasilnya sebagian besar peserta telah mampu membuat laporan keuangan sederhana seperti laporan neraca, laba rugi, perubahan ekuitas, dan arus kas. Secara umum dapat disimpulkan bahwa Peserta telah mampu baik untuk membuat laporan keuangan sederhana baik secara personal maupun secara berkelompok.

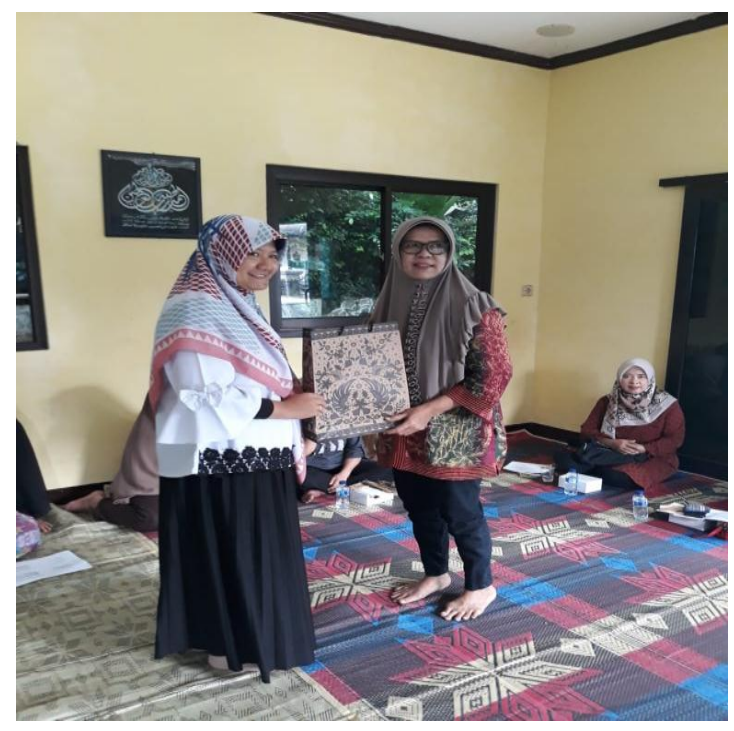

\section{Gambar 6. Pemberian Cinderamata dari Tim PKM kepada Ketua PKK Citra Villa (Sumber: Dokumentasi, 2019)}




\section{Simpulan}

Berdasarkan kegiatan PKM yang telah dilaksanakan dapat ditarik beberapa kesimpulan antara lain sebagai berikut:

1) Pengetahuan peserta dalam hal ini Ibu-Ibu PKK Citra Villa mengenai laporan keuangan sederhana sebelum kegiatan PKM mayoritas berada di kategori hanya cukup menguasai dasar laporan keuangan.

2) Setelah kegiatan PKM diketahui bahwa pengetahuan peserta mengenai laporan keuangan sederhana setelah disampaikan materi mayoritas berada pada kategori menguasai.

3) Sebagian besar peserta setelah kegiatan PKM telah mampu membuat laporan keuangan sederhana seperti laporan neraca, laba rugi, perubahan ekuitas dan arus kas.

4) Dapat disimpulkan juga bahwa terjadi peningkatan pengetahuan dan keterampilan peserta dalam hal pembuatan laporan keuangan sederhana setelah kegiatan ini.

\section{Referensi}

Hanafi, Mamduh M dan Halim, Abdul. (2007). Analisis Laporan Keuangan Edisi Ketiga. STIE YKPN. Yogyakarta.

Jumingan. (2006). Analisis Laporan Keuangan. Cetakan Pertama. PT Bumi Aksara. Jakarta.

Kasmir. (2012). Analisis Laporan Keuangan. PT. Raja Grafindo Persada. Jakarta

Sucipto. (2003). Penilaian Kinerja Keuangan. Jurnal Akuntansi. Program Sarjana Universitas Sumatera Utara. Medan. 